\title{
The Validity of Problem-Solving Based Teaching Materials for The Exploration of Conceptual Change and Metacognitive Skills
}

\author{
Utiya Azizah $^{1}$, Harun Nasrudin ${ }^{2}$, Mitarlis ${ }^{3}$ \\ \{utiyaazizah@unesa.ac.id ${ }^{1}$, harunnasrudin@unesa.ac.id ${ }^{2}$, mitarlis@unesa.ac.id ${ }^{3}$ \}
}

Chemistry Department Universitas Negeri Surabaya, Indonesia ${ }^{1,2,3}$

\begin{abstract}
The aim of the study was describing the validation of Problem-Solving based teaching materials for the exploration of conceptual change and metacognitive skills theoretically and empirically. Research and Development (R \& D) design was utilized in the research method. This study involved three experts for theoretical validation and 31 college students for empirical validation. The instrument used for this study was the validation sheet and questionnaire of college students' perception of problem-solving based teaching materials. The findings research : (a) Theoretical validity from the expert has met the valid include the construct and content categories as well as reliable, (b) empirical validity of the college students' perception of the teaching materials based problem-solving includes the construct and content, all of them have valid categories. From this study, it can be concluded that the Problem-Solving based teaching materials were feasible for use on the exploration of conceptual change and metacognitive skills.
\end{abstract}

Keywords: Validity, teaching materials, problem-solving, exploration conceptual change, metacognitive skills.

\section{Introduction}

Higher education is part of the national education system which has a strategic role in educating the life of the nation. Along with the development of science and technology in the 21 st century, lectures at tertiary institutions are not just material transfers but the lecture process must focus on improving college students' ability to solve problems so as to sharpen their skills and produce output that is ready to face challenges in the 21 st century.

Science lectures (including chemistry) are expected to deliver college students to meet $21 \mathrm{st}$ century abilities, where the abilities include 1) learning and innovating skills which include critical thinking and problem-solving, creative and innovative, as well as being able to communicate and collaborate; 2) skilled at using media, technology, information, and communication) [1]. Efforts are needed to make college students able to have these abilities. One effort that must be done is to add innovation competencies and competencies in the use of technology, information, and communication in chemistry courses.

In the context of learning and innovation skills, lectures in tertiary institutions must be in accordance with national standards higher education, one of which is that the learning outcomes of graduates are achieved through the lecture process in accordance with the demands of the ability to solve problems in his realm of expertise [2]. Basic chemistry courses are held for all 
college students majoring in Chemistry, Biology, Physics, and Mathematics at Faculty of Math and Science Universitas Negeri Surabaya. To meet the standard of lecture process, it is very necessary to develop teaching materials that are in line with the characteristics of national standards higher education. It is also based on the findings of research that the implementation of teaching materials can empower college students' metacognitive skills in mastering chemical concepts [3, 4].

By looking at the description above, teaching materials that are considered appropriate to the needs of college students are teaching materials based on problem-solving models that provide opportunities for college students to restructure cognitive through thinking skills in completing lecture problems. In the problem-solving model there are four steps that must be done, namely: 1) understand the problem, 2) devise a plan, 3) carry out the plan, and 4) look back. In relation to problem-solving Kramarski and Mevarech argue that knowledge of the problem-solving process and the ability to control and manage the problem-solving process are metacognitive skills [5].

In another perspective, it was stated that metacognitive skills as a form of the ability to look at oneself so that what he did can be controlled optimally [6]. College students with metacognitive skills are aware of the strengths and limitations of learning. This means that when college students know their mistakes, they realize to admit that they are wrong, and try to correct it. Learning with a metacognitive skills approach as learning that instills awareness about how to design, monitor, and control what they know; what is needed to do it and how to do it [7]. Learning with metacognitive skills focuses on college student learning activities; help and guide college students if there are difficulties; as well as helping college students to develop selfconcepts of what they do when studying chemistry.

The knowledge that a person already has actually come from the knowledge that is spontaneously obtained from his interactions with the environment. While new knowledge can be sourced from interventions on campus which can both be conflict, congruent, or each stand alone. Under conditions of cognitive conflict, college students are faced with three choices, namely: 1) maintaining their original intuition, 2) revising some of their intuitions through the process of assimilation, and 3) changing their intuitive outlook and accommodating new knowledge. Conceptual changes occur when college students decide on the third choice. In order for the conceptual change process to occur, learning involves the generation and restructuring of conceptions brought by college students before learning [8]. This means that teaching does not transmit knowledge but facilitates and mediates so that the process of negotiation of meaning takes place in the process of conceptual change.

The quality of teaching materials developed will be met, if the teaching materials are in accordance with the criteria, namely validity, practicality, and effectiveness [9]. Teaching material is said to be valid and very valid if there is a consistent relationship of each component of teaching material that is developed with the characteristics of the way lectures are applied in this case lectures based on problem-solving for the exploration of conceptual change and metacognitive skills.

\section{Methods}

This type of research is development research using the Research and Development (R\&D) framework proposed by Borg \& Gall [10]. The product produced in this study is teaching the 
material in the form of Problem-Solving based worksheet that can be used to explore conceptual change and metacognitive skills.

This research has stages, namely preliminary studies and development of teaching materials. In the preliminary study stage, an analysis of concepts and theories related to the teaching material developed and identification of college student characteristics was carried out. At the development stage, an initial draft of teaching material is prepared based on ProblemSolving based design for the exploration of conceptual change and metacognitive skills. The choice of format, media, references, and initial design of teaching materials are the main activities of this stage.

Teaching material that was successfully developed was then validated theoretically (construct and content) by experts in the field of chemistry/chemistry education and validated empirically by college students as users in the form of college students' perceptions of teaching materials based on problem-solving. For the purposes of expert assessment, a validation instrument is prepared to assess and provide input on the developed teaching material. As for college students' perceptions, questionnaires were prepared to provide input on the developed teaching material.

Validation data analysis was performed on each criterion and aspects of the validation sheet including the construct criteria, content criteria, language, and readability, as well as their compatibility with Problem Solving. The percentage data of the validity of the teaching material developed was interpreted according to Table 1 [11].

Table 1. Validity Achievement Category

\begin{tabular}{|c|c|}
\hline $\begin{array}{l}\text { Percentage } \\
\text { Validity }\end{array}$ & Category \\
\hline $85-100$ & Very valid \\
\hline $69-84$ & Valid \\
\hline $53-68$ & Valid Enough \\
\hline $37-52$ & Valid Less \\
\hline $21-36$ & Invalid \\
\hline
\end{tabular}

\section{Result and Discussion}

\subsection{Theoretical Validity}

The results of the analysis of the main concepts relating to teaching materials developed are presented in Table 2 .

By using the concepts of the results of the analysis, a preliminary draft (prototype) of teaching material (draft I) based on Problem-Solving was prepared for the exploration of conceptual changes and metacognitive skills and continued with the validation of teaching materials. The products or problem-solving based teaching materials produced consist of 6 types of worksheet and worksheet Guidelines, namely Law I Thermodynamics (worksheet 1), Thermochemistry, Law Thermodynamics II and III (worksheet 2), Colligative Properties (worksheet 3)), the strength of Acid-Base (worksheet 4), Hydrolysis and buffer solution ( worksheet 5), as well as product of Solubility and Titration (worksheet 6). 
Table 2. The Main Concept in The Material Energetics and Solution

\begin{tabular}{|c|c|}
\hline Materials & Main Concept \\
\hline Energetics & $\begin{array}{l}\text { Temperature, heat, system, environment, state } \\
\text { function, adiabatic process, isotherm process, work, } \\
\text { internal energy, heat capacity, Hess's law, bond } \\
\text { energy, thermochemistry, thermodynamic law I, } \\
\text { thermodynamic law II, thermodynamic law III, } \\
\text { entropy, and free energy }\end{array}$ \\
\hline Solutions & $\begin{array}{l}\text { Dissolution, solubility, vapor pressure, boiling point, } \\
\text { freezing point, osmotic pressure, acid-base theory, } \\
\text { solution properties, pH of the solution, ionization } \\
\text { constant, degree of ionization, the strength of acid- } \\
\text { base, buffer solution, hydrolysis, namesake ion, } \\
\text { Henderson's equation, product of solubility, } \\
\text { indicators, and titration. }\end{array}$ \\
\hline
\end{tabular}

Data on the percentage of validity achievement is obtained through the Focus Group Discussion (FGD) mechanism which is a directed discussion that aims to obtain specific information that is specific. The construct validity with regard to the consistency or logic of the design of teaching materials, and the content validity with regard to the relevance or updating of teaching materials [12].

Data on the percentage of construct validity achievement and its reliability from teaching materials in the form of worksheet and worksheet' Guidelines developed according to validator assessment are presented in Figure 1.

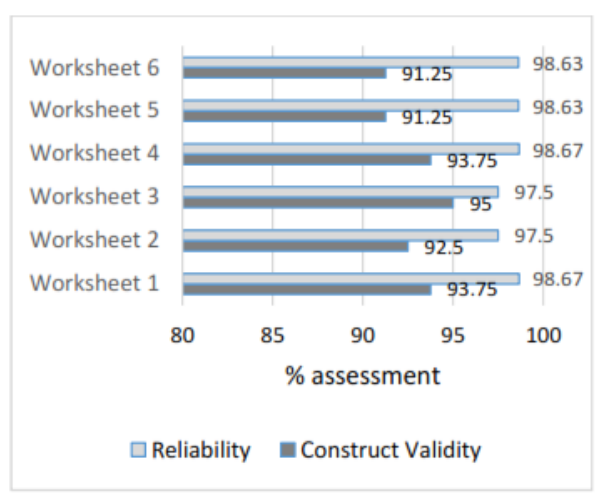

Fig. 1. Construct Validity and Reliability.

Figure 1. shows that the worksheet and worksheet' Guidelines that were assessed had a very valid category according to the criteria used in this study [11]. This means that based on constructs' criteria the worksheet and worksheet' Guidelines have been declared to meet the construct validity requirements by the validators. This justification was reinforced by the final statement of three validators who wrote that it was appropriate to be used with minor improvements. The construct validity also indicates that the learning activity components described in the worksheet and the worksheet' Guidelines covering aspects of format, content, and language are appropriate to practice metacognitive skills in problem-solving in order to 
explore the conceptual changes of college students so that they can be used to support teaching materials which were developed.

The findings of this study, in line with the opinion that states in the preparation of quality products must pay attention to the elements of need (current needs) and the state of the art (conformity to the theory and linkages between all components making up the product compiled) [12]. The components that have been described are fulfilled by problem-solving based teaching materials that have been developed. The assessment of the aspects or components of the worksheet is supported by the findings of the study which state that the things that need to be considered in preparing the worksheet include the aspects of format, content, and language [13].

The percentage of content validity achievement and its reliability from teaching materials in the form of worksheet and worksheet' Guidelines developed according to validator assessment are presented in Figure 2.

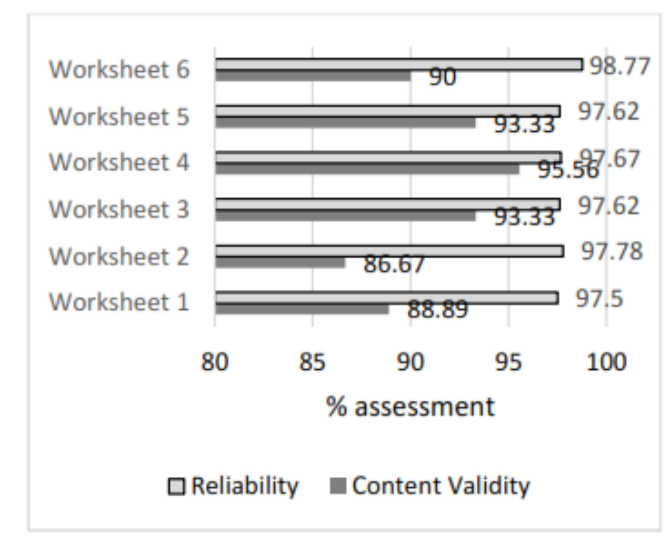

Fig. 2. Content Validity and Reliability.

The findings of this study, in line with the opinion that states in the preparation of quality products must pay attention to the elements of need (current needs) and the state of the art (conformity to the theory and linkages between all components making up the product compiled) [12]. The components that have been described are fulfilled by problem-solving based teaching materials that have been developed. The assessment of the aspects or components of the worksheet is supported by the findings of the study which state that the things that need to be considered in preparing the worksheet include the aspects of format, content, and language [13].Based on Fig. 2., the results of the assessment given by the validator on worksheet and worksheet' Guidance related to content validity and reliability are stated to have fulfilled the content validity requirements, meaning that the criteria or content of the learning design described in worksheet and worksheet' Guidance are in accordance with the contents of teaching materials which was developed. This is supported by the results of research, that the material contained in the worksheet supports the achievement of learning objectives, and the material can be taken from books, magazines, internet, a research journal. The activities contained in worksheet describe the actions or activities carried out by college students [14]. These actions or activities are a means to train college students' metacognitive skills in problem-solving models so that they can help college students to explore conceptual changes that occur in themselves. 
The finding is reinforced by a statement that college students study chemistry and have one of the 21st-century thinking skills if they have problem-solving abilities [15]. Development of teaching materials based on Problem-solving is also in accordance with the government's new policy through Presidential Regulation of the Republic of Indonesia number 8 of 2012 concerning the Level 6 (graduates bachelor) Indonesian National Qualification Framework, which is able to solve problems in their fields. The worksheet is a guide or guide that directs college student learning activities [16].

Revisions are made according to the responses and suggestions given by each expert, either directly or written in the advice column. Suggestions from the expert team and the revisions made by researchers, among others, must improve some unclear picture information as well as emphasize aspects of the presentation of problems and readability so that college students more easily understand and motivate college students in learning.

\subsection{Empirical Validity}

Empirical validity is reviewed from college students' perceptions of problem-solving based teaching materials. using a questionnaire, and the results are presented in Figure 3.

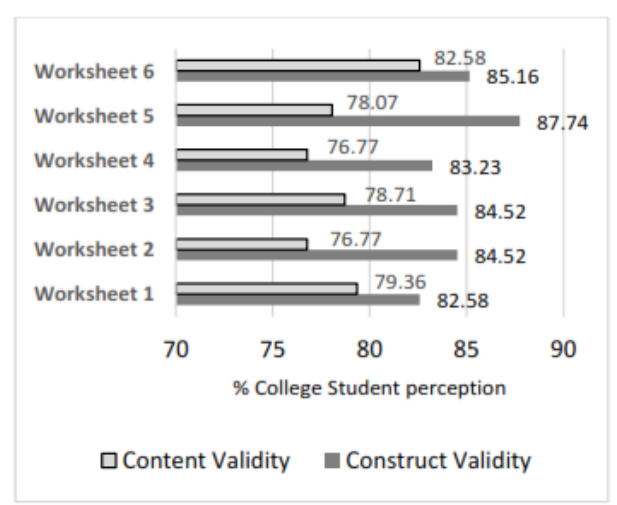

Fig. 3. Content Validity and Construct Validity.

Based on Figure 3, the tendency of college students' perceptions about problem-solving based teaching materials is positive or has empirical validity with valid and very valid categories. This means that in criteria of the construct, worksheet already has an attractive physical appearance, has a size in accordance with the desires, the letters used are comfortable to read, the way of presentation attracts interest and attention, and illustrations (pictures and descriptions) support the understanding of the material. While in criteria of content college students are happy with the worksheet because college students can be actively involved, can study alone at home, attract interest to continue learning, and in general teaching materials are good.

In addition, by using teaching materials, it is easy to understand the problem, easy to determine the plan to solve the problem, easy to implement the problem-solving strategy and check the answers obtained. However, based on the construct criteria there are some comments from college students that there are still colorless pictures in worksheet 6 which causes difficulties for the problem identification process and in worksheet 3 there are still confusing 
images. In criteria of content, there is a statement that has the lowest percentage is, "the existence of this teaching material can be taught at home at its own." It means that some college students have not been able to learn on their own by using worksheet, especially on worksheet 2 Thermochemical material, Law II and III Thermodynamics.

In worksheet 2 , college students have difficulty in the look back' stage, namely giving reasons about the choice of thoughts used to construct concepts or solve problems. In this case, college students have difficulty expressing the change in entropy of chemical reactions at various temperatures. The reasons college students should give are as follows:

"Entropy data for a substance or element are generally contained in a table and are usually measured at $298.15 \mathrm{~K}$. Based on entropy data, the change in entropy of a chemical reaction can be determined. In general, for the reactions illustrated: $\alpha A+\beta B \rightarrow \gamma C+\delta D$

The equation for the change in its entropy:

$$
\begin{aligned}
& \Delta S^{0}=S_{\text {product }}^{0}-S_{\text {reactant }}^{0} \square \square \square \square \text { or } \\
& \square \Delta S^{0}=\left(\gamma S_{C}^{0}+\delta S_{D}^{0}\right)-\left(\alpha S_{A}^{0}+\beta S_{B}^{0}\right)
\end{aligned}
$$

Dependence of entropy of reaction on temperature can be obtained by differentiating the equation of entropy change with temperature. If differentiation is carried out at constant pressure, results are obtained:

$$
\left(\frac{\partial\left(\Delta S^{0}\right)}{\partial T}\right)_{P}=\left(\frac{\partial S_{\text {produk }}}{\partial T}\right)_{P}-\left(\frac{\partial S_{\text {pereaksi }}}{\partial T}\right)_{P}=\frac{\Delta C_{P}^{0}}{T}
$$

Integration of the above equation at To and $\mathrm{T}$ temperatures is obtained:

$$
\Delta S_{T}^{0}=\Delta S_{T_{0}}^{0}+\int_{T_{0}}^{T} \frac{\Delta C_{P}^{0}}{T} d T \square
$$

Using these equations, the change in entropy of a chemical reaction at various temperatures can be determined."

Based on input from construct criteria, content, language, and suitability to problem-solving in empirical validity activities, the teaching material developed was revised so that it could be implemented for exploration of conceptual change and metacognitive skills.

\section{Conclusion}

This research concludes that problem solving-based teaching materials developed that have been feasible and suitable for use in exploration of conceptual change and metacognitive skills, in terms of: (a) Theoretical validity from the expert has met the valid and very valid categories 
as well as reliable includes the construct validities were varying from $91.25 \%$ and $93.75 \%$ with its reliability from $97.5 \%$ and $98.67 \%$, and the content validities were varying from $86.67 \%$ and $93.33 \%$ with its reliability from $97.5 \%$ and $98.77 \%$, (b) empirical validity of the college students' perception of Problem-Solving based teaching materials includes the construct validities were varying from $82.58 \%$ and $87.74 \%$, while content validities were varying from $76.77 \%$ and $82.58 \%$, all of them have valid and very valid categories.

Acknowledgments. The research reported in this article was supported by LPPM Universitas Negeri Surabaya through basic research with funds' PNBP Universitas Negeri Surabaya at 2019. The author thanks chemists and chemistry education as validators and first-year college students of the Chemistry Education program as users who are directly involved in responding to problem-solving based learning materials.

\section{References}

[1] Alismail, H. A. and McGuire, P.: 21 ${ }^{\text {st }}$ Century Standards and Curriculum: Current research and Practice. Journal of Education and Practice. Vol 6, no 6, pp. 150-155. (2015)

[2] Permenristekdikti Nomor 44 Tahun 2015: Standar Nasional Pendidikan Tinggi.

[3] Azizah, U. and Nasrudin, H.: Pemberdayaan Kecakapan Berpikir Siswa SMA Bertaraf Internasional Melalui Pengembangan Perangkat Pembelajaran Materi Redox Reaction Berorientasi Group Investigation Cooperative. Jurnal Pendidikan dan Pembelajaran (JPP), Vol 20, no 2, pp. 141-151. (2014).

[4] Azizah, U. and Nasrudin, H.: Empowerment of Metacognitive Skills through Development of Instructional Materials on the Topic of Hydrolysis and Buffer Solutions. IOP Conf. Series: Journal of Physics: Conference Series, 2018, DOI:10.1088/1742-6596/953/1/012199. (2018).

[5] Kramarski, B. and Mevarech, Z.R.: Enhancing Mathematical Reasoning in the Classroom: The Effect of Cooperatif Learning and Metacognitive Training. American Educational Research Journal. Vol 40, no 1, pp 281-310. DOI: 10.3102/00028312040001281. (2003).

[6] Dinsmore, D. L. Alexander, P. A. and Loughlin, S. M.: "Focusing the conceptual lens on metacognition, self-regulation, and self-regulated learning." Educational Psychological Review, Vol 20, pp. 391-409. (2008).

[7] Fouche, J. and Lamport, M. A.: "Do metacognitive strategies improve student achievement in secondary science classrooms?" Christian Perspectives in Education, Vol 4, no 2, The Berkeley Electronic Press. (2011).

[8] Brooks, J. G. and Brooks, M. G.: In Search of Understanding: the Case for Constructivist Classrooms. Alexandria, VA: Association for Supervision and Curriculum Development, (2003).

[9] McKenney, S. Nieveen, N. and Van den Akker, J.: Computer Support for Curriculum Developers: CASCADE. ETR\&D, 2002, Vol 50, no 4, pp. 25-35. (2002).

[10] Borg, W. R. and Gall, M. D.: Educational Research. New York: Longman, (2003).

[11] Riduwan, Skala Pengukuran Variabel-Variabel Penelitian. Bandung: Alfabeta, (2012)

[12] Plomp, T. and Nieveen, N.: Educational Design Research. Netherlands: SLO, (2013).

[13] Bambang, R.: Dasar-dasar Pembelanjaan, Edisi 4, Yogyakarta: BPFE, (2012).

[14] Devi, P. K. Khairudin, R. and Sofiraeni. Pengembangan Perangkat Pembelajaran. Jakarta: P4TK IPA, (2009).

[15] Bellanca, J. and Brandt, R.: $21^{\text {st }}$ Century Skills: Rethinking How Students Learn. Bloomington, IN: Solution Tree, (2010).

[16] Kibar, Z.B and Ayas, A.: Developing Worksheet about Physical and Chemical Event. Procedia Social and Behavioral Science, Vol 2, pp. 739-743. (2010). 